
університету. - Серія "Регіональна економіка". - Випуск 15 (59). - Редкол.: відп. ред. д.е.н., професор Л.Л. Ковальська. - Луцьк: ІВВ Луцького НТУ, 2018. - 292 с.

УДК 338.49:330.341.1

Рудь Н.Т., д.е.н., професор

Луцький національний технічний університет

\title{
ІННОВАЦІЙНА ІНФРАСТРУКТУРА РЕГІОНУ: СТАН ТА РЕЗЕРВИ РОЗВИТКУ
}

У статті визначено завдання інноваційної інфраструктури забезпечення можливості зниження ризику для безпосередніх учасників інноваційного процесу. Сформовано авторське визначення терміна «інноваційна інфраструктура», її складові підсистеми та функції. Виконано аналіз складових інноваційної інфраструктури відповідно до затвердженої урядом програми. Побудована матриця для управління організаціями інноваційної інфраструктури. Виділено основні проблеми, напрямки та завдання розвитку інноваційної інфраструктури регіону. Систематизовано способи комерціалізації наукових розробок. Виокремлено значення трансферу технологій і його організаційного оформлення.

Ключові слова: регіон, інноваційна інфраструктура, підсистеми, функції, аналіз, трансфер технологій.

Rud N.T.

\section{INNOVATION INFRASTRUCTURE OF THE REGION: STATE AND RESERVES OF DEVELOPMENT}

The article defines the task of innovation infrastructure - ensuring the possibility of reducing the risk for the immediate participants in the innovation process. Formed the author's definition of the term "innovation infrastructure", its components of the subsystem and functions. An analysis of the components of the innovation infrastructure in accordance with the approved government program is performed. A matrix for managing innovation infrastructure organizations has been built. The main problems, directions and tasks of development of innovation infrastructure of the region are highlighted. Methods of commercialization of scientific developments are systematized. The importance of transfer of technologies and its organizational design is singled out.

Key words: region, innovation infrastructure, subsystems, functions, analysis, technology transfer 

університету. - Серія "Регіональна економіка". - Випуск 15 (59). - Редкол.: відп. ред. д.е.н., професор Л.Л. Ковальська. - Луцьк: ІВВ Луцького НТУ, 2018. - 292 с.

Рудь Н.Т.

\section{ИННОВАЦИОННАЯ ИНФРАСТРУКТУРА РЕГИОНА: СОСТОЯНИЕ И РЕЗЕРВЫ РАЗВИТИЯ}

В статье определены задачи инновационной инфраструктуры обеспечение возможности снижения риска непосредственных участников инновационного процесса. Сформировано авторское определение термина «инновационная инфраструктура», ее составляющие подсистемы и функции. Выполнен анализ составляющих инновационной инфраструктуры в соответствии с утвержденной правительством программы. Построена матрица для управления организациями инновационной инфраструктуры. Выделены основные проблемы, направления и задачи развития инновационной инфраструктуры региона. Систематизированы способы коммерциализации научных разработок. Выделены значение трансфера технологий и его организационного оформления.

Ключевые слова: регион, инновационная инфраструктура, подсистемы, функции, анализ, трансфер технологий.

Постановка проблеми. Пошук шляхів стимулювання інноваційного процесу має для економіки України величезне значення. Актуальність теми продиктована з одного боку, катастрофічним скороченням використання результатів НДДКР у промисловості та інших галузях, а 3 іншого, наявним інноваційним потенціалом, представленим цікавими розробками, придатними для комерціалізації. Процес ускладнюється неузгодженістю державної політики, правовими проблемами, а внаслідок цього практично відсутністю інвестицій. Тому, основою стратегічного курсу соціальноекономічного розвитку України має стати реалізація державної політики, спрямованої на інноваційну модель розвитку країни та входження до кола розвинених, високотехнологічних країн.

Оцінка перспектив еволюційного переходу нашої країни до інноваційної економіки показала, що в найближчі 25-30 років при збереженні відносин, що склалися, між наукою, бізнесом і державою він неможливий. Проте «зволікати» 3 переходом до економіки, заснованої на знаннях, не можна, інакше країні загрожує втрата науково-технічного потенціалу і його відтворення. Одним із найважливіших інструментів, що 
Економічні науки: збірник наукових праиь Луиького національного технічного університету. - Серія "Регіональна економіка". - Випуск 15 (59). - Редкол.: відп. ред. д.е.н., професор Л.Л. Ковальська. - Луцьк: ІВВ Луиького НТУ, 2018. - 292 с.

дозволяють прискорити даний процес, є створення і розвиток відповідної інфраструктури.

Цей факт визнаний і на рівні вищого керівництва країни, про що свідчить поставлене ним завдання створення ефективної інноваційної інфраструктури на основі Постанови КМУ №447 від 14.05.2008 р. «Про затвердження Державної цільової економічної програми

«Створення в Україні інноваційної інфраструктури на 2009 - 2013 роки» [1].

В рамках вирішення даного завдання, нами проводиться наукова робота, присвячена дослідженню суті інноваційної інфраструктури, визначенню iii резервів, проблем і напрямів розвитку з урахуванням наявних ресурсів на регіональному рівні.

Аналіз останніх досліджень. Дослідженнями в області розвитку i ефективного функціонування інноваційної інфраструктури регіону займалася невелика кількість науковців, серед яких: Козик В.В. і Жураковська М. [2], Свєшнікова Н.М. і Сілаєв В.І. [3], Фаріон I. і Савчук Л. [4], Жемчужна Л.А. [5] та iн.

Мета статті: розкрити особливості побудови інноваційної інфраструктури, іiі резерви, запропонувати трансфертні механізми взаємодії науки і виробництва.

Виклад основного матеріалу. Сам термін «інфраструктура» перенесений в економіку в кінці 1940-х рр. 3 військового лексикону, де він позначав сукупність постійних споруд допоміжного призначення, обслуговуючих озброєні сили. У широкому сенсі під ним розуміється самостійна сфера економіки, основна функція якої - забезпечення зовнішніх умов господарювання як економічних суб'єктів, так і національної економіки в цілому. Доцільність виділення окремого поняття «інфраструктура інноваційної діяльності» витікає 3 того, що як складова частина загального економічного життя, вона має разом $з$ тим власну внутрішню специфіку, ця діяльність також повинна мати свою певну інфраструктуру, якій властиві не тільки типові, але i характерні лише для неї ознаки i 
Економічні науки: збірник наукових праиь Луиького національного технічного університету. - Серія "Регіональна економіка". - Випуск 15 (59). - Редкол.: відп. ред. д.е.н., професор Л.Л. Ковальська. - Луцьк: ІВВ Луцького НТУ, 2018. - 292 с.

особливості. Вона є єдиною системою взаємопов'язаних i взаємодоповнюючих один одного підсистем і відповідних їм організаційних елементів, необхідних i достатніх для ефективного здійснення діяльності 3 повного забезпечення супроводу інноваційного процесу

Завданням інноваційної інфраструктури є забезпечення можливості зниження ризику для безпосередніх учасників інноваційного процесу шляхом збільшення імовірності вдалого пошуку необхідних для цього суб'єктів, як контрагентів, так i партнерів, на основі збільшення зв'язків всередині інноваційної системи. Таким чином, значна частка ризику інноваційної діяльності знаходиться у прямій залежності від кількості організаційно оформлених взаємозв'язків процесу створення інновації.

Власне діяльність елементів інфраструктури в інноваційній сфері спрямована на надання переважно послуг, ступінь ризику реалізації яких не вищий за середній. Підвищення ризику відбувається саме за рахунок різних видів невизначеності інноваційної діяльності. Проте особливості інноваційного процесу роблять інфраструктурну діяльність у даній сфері також ризикованою. Досить часто отримання прибутку в інноваційній сфері можливе лише після комерційної реалізації нововведення. Це створює додаткове зацікавлення для інфраструктурних елементів та вимагає від них активної позиції у створенні безпосередніх результатів етапів інноваційного процесу на основі механізму участі у прибутках споживача інноваційних послуг через отримання пакету акцій його підприємства.

На нашу думку, інноваційна інфраструктура - це підсистема регіональної інноваційної системи, яка об'єднує певні організації і налагоджує взаємозв'язки з ії складовими, що сприяє створенню, функціонуванню, розвитку і підтримці інноваційного бізнесу на різних стадіях інноваційного процесу, підвищує його ефективність та зменшує тривалість, забезпечує інтеграцію науки i виробництва.. Необхідно відзначити, що інноваційна інфраструктура виконує забезпечуючу, регулюючу, 
Економічні науки: збірник наукових праџь Луцького національного технічного університету. - Серія "Регіональна економіка". - Випуск 15 (59). - Редкол.: відп. ред. д.е.н., професор Л.Л. Ковальська. - Луцьк: ІВВ Луиького НТУ, 2018. - 292 с.

системоутворюючу, посередницьку i інтегруючу функції, $\epsilon$ інструментом реалізації регіональної політики [6].

Систематизовані, згідно наших досліджень, показники Державної програми [1] щодо складових інноваційної інфраструктури наведені в табл. 1.

Таблиця 1

Інноваційна інфраструктура України на кінець 2013 р. (державна програма)*

\begin{tabular}{|c|c|c|}
\hline $\begin{array}{c}\text { Складові } \\
\text { підсистеми }\end{array}$ & Організаційні форми & Кількість \\
\hline \multirow{6}{*}{$\begin{array}{c}\text { Інформаційно- } \\
\text { маркетингова }\end{array}$} & Центри передачі технологій & 50 \\
\hline & $\begin{array}{l}\text { Центри науково-технічної та } \\
\text { інформації }\end{array}$ & 14 \\
\hline & Демонстраційні центри & 20 \\
\hline & $\begin{array}{l}\text { Регіональні контактні пункти із співпраці } 3 \\
\text { іншими країнами у сфері науки і технологій }\end{array}$ & 10 \\
\hline & Підрозділи з питань інтелектуальної власності & 45 \\
\hline & $\begin{array}{l}\text { Структурні підрозділи з моніторингу результатів } \\
\text { наукових досліджень та впровадженню їх на } \\
\text { ринок інтелектуальної власності }\end{array}$ & 15 \\
\hline \multirow{6}{*}{$\begin{array}{l}\text { · } \\
\text { Виробничо- } \\
\text { технологічна }\end{array}$} & $\begin{array}{l}\text { Науково-дослідний } \\
\text { розвитку }\end{array}$ & 1 \\
\hline & Виробничо-інноваційно-інвестиційні комплекси & 10 \\
\hline & 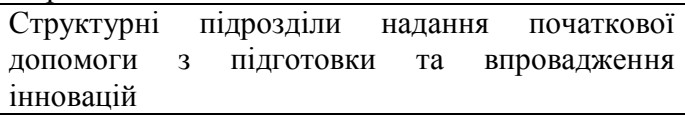 & 20 \\
\hline & Інноваційно-технологічні кластери & 25 \\
\hline & Бізнес-інкубатори & 95 \\
\hline & Бізнес-парки & 25 \\
\hline \multirow{3}{*}{ Фінансова } & Венчурний фонд & 1 \\
\hline & Підрозділи некомерційного партнерства & 25 \\
\hline & Небанківські фінансово-кредитні установи & 2 \\
\hline Кадрова & Спеціалізовані центри підвищення кваліфікації & 27 \\
\hline
\end{tabular}

*складено автором на основі програми [1]

Як показує аналіз табл. 1, в програмі не виділений регіональний розподіл організаційних форм інноваційної інфраструктури; недостатне відображення знаходить кадрова 

університету. - Серія "Регіональна економіка". - Випуск 15 (59). - Редкол.: відп. ред. д.е.н., професор Л.Л. Ковальська. - Луиьк: ІВВ Луиького НТУ, 2018. - 292 с.

складова і фінансова; більш повно представлені інформаційна i виробничо-технологічна складові. Систематичне навчання i підготовка працівників сфери інтелектуальної власності, трансферу технологій та інноваційної діяльності передбачає, згідно з програмою, освоєння 1 пілотної освітньої програми, 1 спеціалізованого курсу, проведення 20 наукових семінарів та конференцій. Ми вважаємо, що цього зовсім недостатньо, щоб підготувати корпус спеціалістів для науково-інноваційної діяльності і інноваційної інфраструктури.

Існуючі тенденції розвитку інноваційної інфраструктури регіонів України свідчать про необхідність певних якісних зрушень в інноваційній сфері, а також реалізації організаційноекономічних засад, спрямованих на забезпечення стабільного інфраструктурного забезпечення регіонального розвитку.

Нами побудована матриця для управління організаціями інноваційної інфраструктури на основі даних моніторингу $\mathrm{MOH}$ станом на 1.01.2009 року. Складові підсистеми інноваційної інфраструктури, запропоновані нами: виробничо-технологічна, кадрова, фінансова, інформаційно-маркетингова, які можуть мати різні організаційні форми. Для аналізу необхідно робити часові зрізи цих баз даних щорічно 3 метою вивчення часової динаміки поповнення матриці організацій інноваційної інфраструктури (табл. 2). 
Таблиця 2

Аналітичні дані для матричної форми бенчмаркінгу, од./\%*

\begin{tabular}{|l|c|c|c|c|c|c|c|c|c|c|}
\hline \multirow{2}{*}{$\begin{array}{c}\text { Регіони (області, } \\
\text { АРК) }\end{array}$} & \multicolumn{9}{|c|}{ Складові підсистеми інноваційної інфраструктури регіону } \\
\cline { 2 - 13 } & $\begin{array}{c}\text { Виробничо- } \\
\text { технологічна }\end{array}$ & \multicolumn{2}{|c|}{ Кадрова } & \multicolumn{2}{c|}{ Фінансова } & \multicolumn{2}{c|}{$\begin{array}{l}\text { Iнформаційно- } \\
\text { маркетингова }\end{array}$} & \multicolumn{2}{c|}{ Всього } \\
\hline 1 & 2 & 3 & 4 & 5 & 6 & 7 & 8 & 9 & 10 & 11 \\
\hline Україна & 63 & 100 & 32 & 100 & 19 & 100 & 79 & 100 & 193 & 100 \\
\hline АР Крим & 2 & 3,17 & 1 & 3,13 & 1 & 5,26 & 5 & 6,33 & 9 & 4,67 \\
\hline Вінницька & - & - & 3 & 9,38 & - & - & 4 & 5,06 & 7 & 3,63 \\
\hline Волинська & 2 & 3,17 & 1 & 3,13 & 1 & 5,26 & 5 & 6,33 & 9 & 4,67 \\
\hline Дніпропетровська & 1 & 1,59 & 1 & 3,13 & 1 & 5,26 & 2 & 2,53 & 5 & 2,59 \\
\hline Донецька & 3 & 4,76 & 1 & 3,13 & 1 & 5,26 & 5 & 6,33 & 10 & 5,18 \\
\hline Житомирська & 1 & 1,59 & 3 & 9,38 & - & - & 7 & 8,86 & 11 & 5,70 \\
\hline Закарпатська & 2 & 3,17 & - & - & - & - & 1 & 1,27 & 3 & 1,55 \\
\hline Запорізька & 1 & 1,59 & - & - & - & - & 2 & 2,53 & 3 & 1,55 \\
\hline Ів.-Франківська & 4 & 6,35 & 3 & 9,38 & 2 & 10,53 & 4 & 5,06 & 13 & 6,74 \\
\hline Київська & - & - & - & - & - & - & 1 & 1.27 & 1 & 0,52 \\
\hline Кіровоградська & - & - & 1 & 3,13 & 1 & 5,26 & 3 & 3,80 & 5 & 2,59 \\
\hline Луганська & 5 & 7,94 & 6 & 18,75 & - & - & 2 & 2,53 & 13 & 6,74 \\
\hline Львівська & 7 & 11,11 & 1 & 3,13 & - & - & 2 & 2,53 & 10 & 5,18 \\
\hline Миколаївська & - & - & 3 & 9,38 & - & - & 8 & 10,13 & 11 & 5,70 \\
\hline Одеська & 2 & 3,17 & 1 & 3,13 & - & - & 1 & 1,27 & 4 & 2,07 \\
\hline Полтавська & 3 & 4,76 & 1 & 3,13 & 9 & 47,37 & 2 & 2.53 & 15 & 7,77 \\
\hline Рівненська & 11 & 17,46 & - & - & - & - & 3 & 3,80 & 14 & 7,25 \\
\hline
\end{tabular}


Продовження таблиця 2

Аналітичні дані для матричної форми бенчмаркінгу, од./\%*

\begin{tabular}{|c|c|c|c|c|c|c|c|c|c|c|}
\hline Сумська & 1 & 1,59 & - & - & - & - & 1 & 1,27 & 2 & 1,04 \\
\hline Тернопільська & - & - & - & - & - & - & 2 & 2.53 & 2 & 1,04 \\
\hline Харківська & 5 & 7,94 & - & - & 1 & 5,26 & 4 & 5,06 & 10 & 5,18 \\
\hline Херсонська & 2 & 3,17 & - & - & 1 & 5,26 & 3 & 3,80 & 6 & 3,11 \\
\hline Хмельницька & 5 & 7,94 & 2 & 6,25 & - & - & 4 & 5,06 & 11 & 5,70 \\
\hline Черкаська & 1 & 1,59 & - & - & - & - & 2 & 2,53 & 3 & 1,55 \\
\hline Чернівецька & 1 & 1,59 & - & - & 1 & 5,26 & 2 & 2,53 & 4 & 2,07 \\
\hline Чернігівська & - & - & - & - & - & - & 1 & 1,27 & 1 & 0,52 \\
\hline м. Київ & 4 & 6.35 & - & - & - & - & 1 & 1,27 & 5 & 2,59 \\
\hline м. Севастополь & - & - & 4 & 12,5 & - & - & 2 & 2,53 & 6 & 3,11 \\
\hline
\end{tabular}

*складено автором на основі даних Міністерства освіти і науки [7, с.25] 
Економічні науки: збірник наукових праиь Луиького національного технічного університету. - Серія "Регіональна економіка". - Випуск 15 (59). - Редкол.: відп. ред. д.е.н., професор Л.Л. Ковальська. - Луцьк: ІВВ Луцьького НТУ, 2018. - 292 с.

Суттєвою ознакою розвитку підприємств інноваційної інфраструктури в Україні, як видно із табл. 2, є неповнота i нерівномірність їх розподілу за регіонами. Так, є області, де певні елементи інноваційної інфраструктури більш розвинені порівняно з іншими регіонами. Зокрема, у Полтавській області створено 3 інноваційних бізнес-інкубатори, 9 небанківських фінансово-кредитних установ, 1 навчальний центр, 1 консультаційний центр, 1 центр науково-технічної та економічної інформації; у Луганській - 5 науково-навчальних центрів, 4 науково-впроваджувальних підприємства, в Рівненській області діє 8 науково-впроваджувальних підприємств, в Івано-Франківській представлені майже всі елементи інноваційної інфраструктури - технологічний парк, інноваційний бізнес-інкубатор, дослідницький центр 3 питань інновацій, центр науково-технічної та економічної інформації, інноваційно-технологічний кластер, 3 центри комерціалізації інтелектуальної власності та 3 навчально-наукових центри.

Також достатньо розвиненою порівняно 3 іншими регіонами України є інноваційна інфраструктура у Донецькій, Хмельницькій, Житомирській, Миколаївській, Львівській та Харківській областях. Разом 3 тим, є області, де з усіх елементів інноваційної інфраструктури представлено лише технопарк i регіональний центр науково-технічної та економічної інформації (Сумська), 1 центр інновацій та трансферу технологій та 1 центр комерціалізації інтелектуальної власності (Тернопільська) або лише інноваційний центр (Чернігівська, Київська). Можна зробити висновок, що інноваційна інфраструктура в регіонах держави існує в якості окремих розрізнених елементів.

Волинська область має показники формування інноваційних структур на рівні середньоукраїнських: Волинський центр передачі новітніх технологій, Волинський регіональний центр інвестицій та розвитку, навчальний центр, інвестиційний фонд, три інноваційних центри, відкритий в 2008 році інноваційний бізнес-інкубатор, центр науково-технічної і економічної інформації. В рамках Держпрограми необхідно деталізувати вклад конкретного регіону в 
Економічні науки: збірник наукових праџь Луцького національного технічного університету. - Серія "Регіональна економіка". - Випуск 15 (59). - Редкол.: відп. ред. д.е.н., професор Л.Л. Ковальська. - Луцьк: ІВВ Луичького НТУ, 2018. - 292 с.

формування регіональних інноваційних інфраструктур. Волинським органам влади, науковій спільноті слід активізувати роботу над формуванням інноваційної інфраструктури регіону. Підтвердженням активізації процесів взаємодії $\epsilon$ проведення «круглих столів» 3 адміністрацією міста, області щодо залучення вищої школи до реалізації інноваційних проектів i комерціалізації.

Дослідження, що проводяться нами, доводять, що у Волинській області відсутні всі компоненти інноваційної інфраструктури. Дана ситуація обумовлена наступними чинниками:

- орієнтація економіки Волинської області на крупні промислові підприємства i, як наслідок, нерозвиненість малого інноваційного бізнесу;

- відсутність гарантії захисту інтелектуальної власності і недосконалість нормативно-правової бази у сфері фінансування інновацій на державному та регіональному рівнях.

Слід відзначити, що у Волинській області є достатньо розвинена банківська система. Саме це дозволить привертати кредитні ресурси для розвитку науково-інноваційної діяльності. Гострою проблемою на сьогоднішній день $є$ відсутність різного типу фондів (венчурних, гарантійних, інноваційних). Наявність їх дозволила б розвивати інвестиційно-інноваційну діяльність, більш динамічно i злагоджено акумулювати при цьому фінансові ресурси юридичних і фізичних осіб.

Таким чином, створення інноваційної інфраструктури за підтримки влади Волинської області дозволить об'єднати на виробничих майданчиках потенціал наукових співробітників із запитами реального бізнесу i здійснити комерціалізацію наукових розробок.

Основними напрямами розвитку інноваційної інфраструктури регіону вважаємо:

1) побудову інститутів, що акумулюють фінансові i інвестиційні ресурси області в інновації;

2) створення центрів, що спеціалізуються на наданні інформаційних послуг (консалтинг, технологічний аудит); 
Економічні науки: збірник наукових праџь Луцького національного технічного університету. - Серія "Регіональна економіка". - Випуск 15 (59). - Редкол.: відп. ред. д.е.н., професор Л.Л. Ковальська. - Луиьк: ІВВ Луиького НТУ, 2018. - 292 с.

3) організацію центру трансферу технологій, центру експертизи;

4) вирішення питань пов'язаних 3 підготовкою i перепідготовкою кадрів;

5) вдосконалення податкової політики регіону (ухвалення обласних нормативно-правових актів, що встановлюють пільги для інвестицій в інноваційний процес);

6) застосування механізму страхування інноваційних ризиків.

На нашу думку, найбільш потужним чинником формування i розвитку інноваційної інфраструктури $\epsilon$ затребуваність іiі підприємцями, малим, середнім і крупним інноваційним бізнесом. Найкращим варіантом розвитку інноваційної інфраструктури є налагодження тісного контакту між державою, безпосередньо зацікавленою в зростанні інновацій та науковими установами і бізнесом, здатним здійснити фінансування наукових розробок.

Доцільно виділити наступні основні проблеми, що негативно впливають на розвиток вітчизняної інноваційної інфраструктури:

- відсутність розвинутих інфраструктурних елементів сприяння інноваційним проектам, таких як технопарки, спеціалізовані бізнес-інкубатори і венчурні фонди;

- відсутність сучасних механізмів освоєння технологічних нововведень і виведення їх на ринок. В розвинутих країнах існує окремий сектор економіки, що забезпечує необхідні умови (інфраструктура) для розвитку малого, середнього та крупного бізнесу;

- незавершеність більшості наукових розробок через відсутність ефективно побудованої системи трансферу технологій;

- відсутність на внутрішньому ринку платоспроможного попиту на високотехнологічну продукцію.

Для розв’язання вищезазначених проблем необхідно:

- освоювати у виробництві вітчизняні і зарубіжні науковотехнологічні розробки і винаходи 3 подальшим передаванням 
Економічні науки: збірник наукових праџь Луцького національного технічного університету. - Серія "Регіональна економіка". - Випуск 15 (59). - Редкол.: відп. ред. д.е.н., професор Л.Л. Ковальська. - Луцьк: ІВВ Луцького НТУ, 2018. - 292 с.

результатів для широкого використання в економіці і на зовнішньому ринку;

- розвивати експортну базу і збільшувати валютні надходження унаслідок більш інтенсивного включення економіки окремих регіонів в систему міжрегіональних, міжнародних економічних зв'язків;

- наповнити внутрішній ринок конкурентоздатними товарами і послугами виробничого і споживчого призначення;

- дослідити на локальному рівні різні варіанти освоєння нових форм господарювання, пристосованих до умов внутрішнього ринку;

- розширити коло потенційних інвесторів за рахунок представників ринку венчурного інвестування, а також за рахунок середнього і крупного бізнесу;

- удосконалити галузеву структуру виробництва i прискорити соціально-економічний розвиток територій;

- надавати фінансову підтримку на ранніх стадіях становлення інноваційних проектів;

- допомагати у пошуку партнерів і надавати різного виду послуги з «супроводу» реалізації інноваційних проектів;

- допомагати в одержанні доступу до найбільш доступних офісних і виробничих приміщень;

- забезпечувати інформацією.

Як свідчить міжнародний досвід, найбільш перспективним механізмом економічної стабілізації держави $є$ технологічний трансфер, який передбачає передачу «ноу-хау», нових технологій та технологічного обладнання зацікавленим споживачам. Трансфер технологій, якщо він добре організований, успішно та інтенсивно функціонує, стає основним способом реалізації стратегічних альтернатив економічного розвитку. В останні часи період від створення технологій до ії освоєння значно скоротився і ті країни, які в змозі швидко та ефективно їх використовувати в усіх сферах людської діяльності, забезпечують собі отримання більшої доданої вартості, більших прибутків, створення більшої кількості високооплачуваних місць. Сьогодні існують численні 
Економічні науки: збірник наукових праџь Луцького національного технічного університету. - Серія "Регіональна економіка". - Випуск 15 (59). - Редкол.: відп. ред. д.е.н., професор Л.Л. Ковальська. - Луиьк: ІВВ Луиького НТУ, 2018. - 292 с.

позитивні приклади того, як країни з ринковою економікою за короткий час подолали економічну кризу, відсталість, безробіття та увійшли до кола високорозвинених індустріальних країн світу завдяки залученню прогресивних технологій на міжнародних ринках.

Вважаємо за доцільне виділити основні труднощі, які гальмують процеси трансферу технологій:

1) не розроблені чіткі механізми із залучення й використання результатів науково-технологічної діяльності в господарський обіг;

2) відсутні критерії оцінки ринкової вартості науковотехнічної продукції;

3) кадрова проблема (процес комерціалізації вимагає комплексного підходу, зусиль і знань цілого колективу фахівців).

Необхідно також звернути увагу на те, що крім нестачі висококваліфікованих спеціалістів на перешкоді стають наступні фактори [8]:

- корупція i, як наслідок, непрозорість українських компаній;

- митний режим, що перешкоджає, як ввезенню, так i вивезенню високотехнологічних товарів;

- відсутність технічної інфраструктури;

- відсутність технологічної пропрацьованості багатьох складових просування інноваційної продукції на ринок та відсутність кваліфікованих кадрів із маркетингу інновацій.

Трансфер технологій - це процес розповсюдження технологічних знань прикладного характеру і досвіду відносно процесів, методів виробництва та інноваційних продуктів в середині галузі, між галузями, а також між країнами. Трансфер технологій включає в себе комерціалізацію наукових розробок, тобто передачу нової технології (новації) у комерційне використання, а також розповсюдження вже існуючих технологій у вигляді надання ліцензій та патентів.

Він здійснюється для реалізації таких завдань: розробки і виробництва нової продукції; підвищення якості та покращення 
Економічні науки: збірник наукових праиь Луиького національного технічного університету. - Серія "Регіональна економіка". - Випуск 15 (59). - Редкол.: відп. ред. д.е.н., професор Л.Л. Ковальська. - Луцьк: ІВВ Луцького НТУ, 2018. - 292 с.

властивостей продукції; зниження собівартості продукції; підвищення наукового та технологічного рівнів виробництва; економії енергії та сировини; удосконалення організації управління виробництвом.

Виділяють три основні форми трансферу технологій:

1) внутрішній трансфер - передача технології від одного підрозділу організації іншому;

2) квазівнутрішній трансфер - рух технології в середині альянсів, союзів, об' єднань самостійних юридичних осіб;

3) зовнішній трансфер - розповсюдження технології, в якому беруть участь незалежні розробники і покупці технології.

Важливим елементом трансферу технологій $\epsilon$ процес комерціалізації результатів НДДКР. Річ у тому, що створена технологія (за умови іiі технічної винятковості і затребуваності ринком) набуває комерційної цінності тільки в двох випадках: якщо підтверджені виняткові права (монопольні) на іiі використання (патент на винахід, свідоцтво на корисну модель та ін.) або, якщо технологія містить ноу-хау. Комерціалізація результатів НДДКР, як інноваційного продукту, здійснюється через передавання прав на них, що може бути здійснене шляхом [9]:

інших осіб;

передавання (відступлення) всіх майнових прав

- $\quad$ внесення прав на об'єкти права інтелектуальної власності (ОПІВ) до статутного капіталу підприємства;

- передавання права користування ОПІВ іншій юридичній або фізичній особі.

До основних способів комерціалізації результатів НДДКР належать: промислова кооперація; франшиза; лізинг; технічна допомога. Переваги та недоліки вищеперелічених способів комерціалізації наведені у таблиці 2. 
Аналітичні дані для матричної форми бенчмаркінгу, од./\%*

Таблиця 2

\begin{tabular}{|c|c|c|}
\hline $\begin{array}{c}\text { Способи } \\
\text { комерціалізації }\end{array}$ & Переваги & Недоліки \\
\hline $\begin{array}{c}\text { Промислова } \\
\text { кооперація }\end{array}$ & $\begin{array}{l}\text { - дешева робоча сила в одній з двох країн; } \\
\text { - підвищення продуктивності в одній країні } \\
\text { шляхом використання ноу-хау або капіталу з другої } \\
\text { країни; } \\
\text { - полегшення доступу на зарубіжний ринок або } \\
\text { освоєння внутрішнього ринку іноземним } \\
\text { підприємством-партнером; } \\
\text { - зниження податків, митних та ін. зборів, беручи } \\
\text { до уваги наявність статусу вітчизняного } \\
\text { підприємства. }\end{array}$ & $\begin{array}{l}\text { - неоднаковий ступінь взаємозалежності партнерів } \\
\text { з кооперації; } \\
\text { - високий ступінь залежності підрядника від } \\
\text { замовника; } \\
\text { - короткий термін дії. }\end{array}$ \\
\hline $\begin{array}{l}\text { Технічна } \\
\text { допомога }\end{array}$ & $\begin{array}{l}\text { - кваліфікована допомога спеціаліста у певній } \\
\text { сфері; } \\
\text { - можливий супровід вченого та використання } \\
\text { спеціальних разових заходів, що вимагає високої } \\
\text { кваліфікації і спеціального досвіду. }\end{array}$ & $\begin{array}{l}\text { - великі витрати при залученні консалтингових } \\
\text { фірм; } \\
\text { - використовування у сферах, де використання } \\
\text { власного персоналу неможливе; } \\
\text { - можливі великі витрати на обслуговування } \\
\text { процесу. }\end{array}$ \\
\hline Франшиза & $\begin{array}{l}\text { - у більшості випадків товари й послуги, що } \\
\text { реалізуються під одним товарним знаком, мають } \\
\text { однакову якість та інфраструктуру наданих послуг; } \\
\text { - за рахунок контролю якості з боку франчайзера } \\
\text { франчайзингові фірми зазвичай надають вищий } \\
\text { рівень обслуговування; } \\
\text { - франчайзі, як власники, надають споживачеві } \\
\text { послуги з більшим ступенем особистої участі. }\end{array}$ & $\begin{array}{l}\text { - залежність успіху діяльності франчайзі від } \\
\text { репутації торгової марки франчайзера; } \\
\text { - ризик невідповідності методів ведення } \\
\text { підприємницької діяльності; } \\
\text { - неможливість виходу } 3 \text { бізнесу до закінчення } \\
\text { терміну дії франчайзингової угоди без матеріальних } \\
\text { втрат; } \\
\text { - обмеження територіальної експансії франчайзі } \\
\text { закріпленою за ним у договорі територією. }\end{array}$ \\
\hline
\end{tabular}


Продовження таблиці 2

Аналітичні дані для матричної форми бенчмаркінгу, од./\%*

\begin{tabular}{|c|c|c|}
\hline Лізинг & $\begin{array}{l}\text { - гнучкий графік виплат; } \\
\text { - термін лізингу може бути значно більшим } \\
\text { терміну кредиту, нерівномірність витрат і } \\
\text { надходжень грошових коштів; } \\
\text { - не вимагається застава; } \\
\text { - можливість закрити лізингову операцію або } \\
\text { повернути предмет лізингу достроково; } \\
\text { - об'єкт лізингу ставиться на баланс } \\
\text { лізингоодержувача і амортизується, що } \\
\text { дозволяє оптимізувати базу оподаткування. }\end{array}$ & $\begin{array}{l}\text { - ризик морального старіння устаткування; } \\
\text { - можливість ризику зміни процентних } \\
\text { ставок за кредитами; } \\
\text { - вартість лізингу більша, ніж ціна купівлі } \\
\text { або банківського кредиту. }\end{array}$ \\
\hline
\end{tabular}

*складено автором за $[10,11,12]$.

岁 
Економічні науки: збірник наукових прачь Луиького національного технічного університету. - Серія “Регіональна економіка". - Випуск 15 (59). - Редкол.: відп. ред. д.е.н., професор Л.Л. Ковальська. - Луцьк: ІВВ Луцького НТУ, 2018. - 292 с.

Одним із результатів функціонування інноваційної інфраструктури регіону має бути застосування форм трансферу технологій, що робить їх максимально доступними для малого і середнього інноваційного бізнесу. Центри трансферу технологій (ЦТТ) - найбільш масштабний елемент, який повинен супроводжувати науково-технологічні розробки практично на всіх етапах iї реалізації. В основному ЦТТ фокусують свою діяльність на трансфері критичних технологій, що входять в пріоритетні напрямки розвитку науки, технології і техніки.

Деякі інші необхідні елементи інфраструктури знаходяться в процесі формування - такі як відділи трансферу технологій в науково-дослідних інститутах і вузах, так само створюється система поетапного фінансування проектів. Даний комплекс $є$ сукупністю взаємозв'язаних структур i організаційних елементів, необхідних для створення умов i ефективної реалізації інноваційно-інвестиційних проектів. Кожний iз представлених елементів інноваційної інфраструктури має виконувати певні функції на різних етапах інноваційного процесу. ЦТТ $є$ ключовим організаційним елементом даної мережі, що з одного боку координує діяльність всіх структур, а з іншого боку здійснює безпосередньо комплекс робіт 3 формування і управління інтелектуальною власністю своїх партнерів.

Висновки. Таким чином, створення цілісної системи взаємодії всіх елементів інфраструктури відкриває нові можливості комерціалізації розробок, отриманих при виконанні регіональних науково-технологічних програм і проектів, для малого інноваційного підприємництва. Для цього потрібна тісна взаємодія центральних, регіональних i муніципальних адміністрацій, фінансових організацій, представників промислових підприємств, керівників вузів і НДІ, представників ЦТТ та інших інноваційних структур. Проте подібна робота не може бути проведена швидко. Активізація інноваційної діяльності вимагає, 3 одного боку, державного управління i координації дій всіх ії суб'єктів, 3 іншої - інтеграції всіх зацікавлених структур в реалізації інноваційних процесів, 
Економічні науки: збірник наукових прачь Луиького національного технічного університету. - Серія “Регіональна економіка". - Випуск 15 (59). - Редкол.: відп. ред. д.е.н., професор Л.Л. Ковальська. - Луиьк: ІВВ Луиького НТУ, 2018. - 292 с.

залучення інвестицій, створення умов, сприяючих інноваційному процесу і освоєнню досягнень науки в економіку регіону.

Для досягнення цієї мети необхідно затвердити концепцію створення національної інноваційної системи на урядовому рівні, регіональних інноваційних систем на конкретних територіях. Особливо слід акцентувати увагу на регіональному рівні, який створює найкраще середовище та простір для інноваційної діяльності. В Україні цей формат діяльності та управління інноваційними процесами лише створюється. Тому необхідно активізувати роботу щодо пошуку форм такої діяльності, розробки оптимальної, прив'язаної до ситуації в окремих регіонах структури РІС, шляхів розвитку регіонального ринку інновацій.

1. Постанова КМУ №447 від 14.05.2008p. «Про затвердження Державної цільової економічної програми «Створення в Україні інноваційної інфраструктури на 2009 - 2013 роки».

2. Козик В., Жураковська М. Проблеми функціонування регіональної інноваційної інфраструктури (на прикладі Львівської області). Галицький економічний вісник. 2010. №1(26). С.19-25.

3. Свєшнікова Н.М., Сілаєв В.І. Інноваційна інфраструктура як складова сталого економічного розвитку економіки Донецького регіону. URL:http://www.confcontact.com/2009reform/2_sveshnik.htm.

4. Фаріон І., Савчук Л. Регіональні аспекти розвитку інноваційної інфраструктури. Економічний аналіз. 2010. Випуск 5. С.375-379.

5. Жемчужна Л.А. Інституційні елементи Донецького регіону. Економіка. Управління. Інновації. 2010. №2(4).

6. Рудь Н.Т., Герасимчук 3.В. Інфраструктурне забезпечення інноваційних процесів: монографія. Луцьк: Вежа-Друк, 2013. 260 с.

7. Стратегія інноваційного розвитку України на 2010-2020 роки в умовах глобалізаційних викликів: [збірник] / М.В. Стріха, В.С. Шовкалюк, Т.В. Боровіч, Ж.І. Дубчак, А.О. Сєдов. Київ: Прок-Бізнес, 2009. 40 с.

8. Комерціалізація і технологія в сучасних умовах в Україні. URL: htt:// experts.in.ua/baza/analytic/index.php? ELEMENT ID $=31888$.

9. Цибулев П.М. Маркетинг интеллектуальной собственности. Киев: Инт. интел. собств. и права, 2004. 184c.

10. Недоліки для франчайзі. URL: http://www.etm.dp.ua/?p=635.

11. Переваги та недоліки лізингу. URL: http://leasing.vseto.com/?p=460. 
Економічні науки: збірник наукових пращь Луцького національного технічного університету. - Серія “Регіональна економіка". - Випуск 15 (59). - Редкол.: відп. ред. д.е.н., професор Л.Л. Ковальська. - Луцьк: ІВВ Луиького НТУ, 2018. - 292 с.

12. Фінансування зовнішньої торгівлі. URL: http://www.readbookz.com/book /36/1614.htmf 